\title{
ANALYSIS OF PHYSICAL-CHEMICAL PROCESSES OCCURRING ON THE BOUNDARY BETWEEN THE MELT AND NON-STICK COATING
}

\author{
T. R. Gilmanshina ${ }^{1}$, I. V. Dubova ${ }^{1}$, N. V. Vasyunina ${ }^{1}$, A. A. Kovaleva ${ }^{1}$ \\ ${ }^{1}$ Siberian Federal University (Krasnoyarsk, Russia)
}

E-mail: gtr1977@mail.ru

\section{A UTHOR'S INFO \\ T. R. Gilmanshina, Cand. Eng., Associate Prof., I. V. Dubova, Cand. Eng., Associate Prof.; N. V. Vasyunina, Cand. Eng., Associate Prof.; A. A. Kovaleva, Cand. Eng., Associate Prof. \\ Dr. Eng., Prof. I.E. Illarionov participated in this research.}

\section{Key words:}

shear stress, shift, thin-walled tube, tube torsion, Huber-Mises's condition, Tresca-SaintVenant's condition, Nadai's and Ludwik's descriptions.

\begin{abstract}
A B S T RAC T
This research presents the results of thermodynamic analysis of interaction between iron-carbon melts and graphite-containing non-stick coating during manufacture of iron castings in the temperature interval from 500 to $1400{ }^{\circ} \mathrm{C}$. SCh20 cast iron and aqueous-base non-stick coating with use of natural hidden crystalline graphite were taken as the objects in this research. The processes on the boundary between the melt and non-stick coating, its reduction by the melt components (carbon, silicon) and interaction with dissolved oxygen were considered during evaluation of interaction between the system phase components. The conducted thermodynamic calculations displayed that reactions of interaction between coating carbon and oxygen are passing mainly to carbon (II) which forms reducing atmosphere in the mould cavity and provides decrease of burning-on. Forming of mixed $\mathrm{Fe}_{3} \mathrm{O}_{4}$ during reaction of coating carbon with $\mathrm{Fe}$ (III) oxide is confirmed. The forming $\mathrm{CO}$ interacts only with $\mathrm{Fe}_{2} \mathrm{O}_{3}$. It should be noted that presence of pyrite in coating composition through the chain of reducing and oxidizing processes lead to forming of oxysulfates and oxysulfides, which support forming of burning-on on the surface of castings. It is concluded that thermodynamic analysis of chemical reactions of interaction between coating phases and melt components as well as mould atmosphere can help to predict operating efficiency of carbon-containing coating during its development.
\end{abstract}

\section{Introduction}

Burning-on on the surface of iron castings, manufactured in an expendable sand-loam moulds, is still actual problem until today, despite numerous researches [1-3]. Two causes of burning-on forming are known: the first is connected with mechanical melt penetration in mould pores and sintering, while the second is based on chemical interaction between the system components, with forming iron silicates $(\mathrm{FeO})_{m}\left(\mathrm{SiO}_{2}\right)_{n}$ of variable composition [4-8]. $\mathrm{FeO}$ and $\mathrm{Fe}_{3} \mathrm{O}_{4}$ oxides play the main role in forming of silicates, and interaction between $\mathrm{Fe}_{2} \mathrm{O}_{3}$ and $\mathrm{SiO}_{2}$ is possible only in the narrow temperature area [9]. Use of non-stick coatings provides prevention of metal interaction with a mould; compositions of these coatings can be chosen depending on type of poured alloy and composition of moulding and core mixtures. The effect of coatings can be explained by thermodynamic analysis of reactions occurring between the main component of coating filling agent and iron oxides [9-11].

Graphite is the most frequently used filling agent for non-stick coatings in manufacture of iron castings. Graphite creates the reducing atmosphere in a mould cavity owing to carbon oxidation by oxygen and carbon oxides which are presented in the casting mould atmosphere. These reactions are heterogeneous because they pass on two interphase surfaces: solid graphite particles gas phase and metal melt - gas phase. According to the kinetic relationships, the equilibrium constants of carbon oxidation processes by gases depend on gas phase composition in the mould atmosphere and on its temperature, as well as on thermodynamic activity of carbon and impurity phases which are presented in graphite [12]. In addition to refractory filling agent, the phases contained in additives and binders of coatings have the effect on the process of burning-on forming.

The aqueous non-stick coating on the base of hidden crystalline graphite from the Krasnoyarsk territory deposits was developed and is putting into practice in the Institute of non-ferrous metals and materials science of the Siberian federal university [13-15]. The effect of graphite parameters (such as average size of particles, total surface, shape and roughness coefficients, structure parameters, content of carbon and impurity phases), which are varying during graphite activation, on surface cleanness of castings is analyzed in the a.m. works. At the same time, the advantages of this coating from the point of view of thermodynamic possibility of passing the chemical reactions between the melt and coating components (both preventing and supporting burning-on forming) is not substantiated at present time.

The aim of this work was conducting of thermodynamic analysis of chemical reactions during interaction between coating phases and melt components, as well as mould atmosphere; it allows to substantiate operating efficiency of non-stick coating.

\section{The technique of experiment}

Isobaric-isothermal potential $\Delta G_{T}$ (Gibbs energy) is considered as an energetic parameter which value can be the base for evaluation of possibility of interaction of two phases. Chemical interaction can pass when $\Delta G_{T}<0$ and 


\begin{tabular}{|c|c|c|c|c|c|}
\hline \multirow[t]{2}{*}{ Phase } & \multicolumn{5}{|c|}{ Temperture, ${ }^{\circ} \mathrm{C}$} \\
\hline & 20 & 450 & 570 & 700 & 900 \\
\hline Graphite (C) & 78.9 & 83.0 & 86.6 & 84.0 & 28.1 \\
\hline Diopside $\left(\mathrm{CaMg}\left(\mathrm{SiO}_{3}\right)_{2}\right)$ & 0.56 & 0.59 & 0.61 & 1.20 & 2.93 \\
\hline Muscovite $\left(\mathrm{KAl}_{2}\left(\mathrm{AlSi}_{3} \mathrm{O}_{10}\right)\right)$ & 6.23 & 2.18 & 2.27 & 4.64 & 4.53 \\
\hline Quartzite $\left(\mathrm{SiO}_{2}\right)$ & 2.71 & 2.85 & 1.47 & 1.43 & 2.03 \\
\hline Nacrite $\left(\mathrm{H}_{4} \mathrm{Al}_{2} \mathrm{Si}_{2} \mathrm{O}_{9}\right)$ & 0.78 & - & - & - & - \\
\hline Anorthite $\left(\mathrm{Ca}_{0,66} \mathrm{Na}_{0,34} \mathrm{Al}_{1,66} \mathrm{Si}_{2,34} \mathrm{O}_{8}\right)$ & 4.82 & 3.53 & 3.36 & - & - \\
\hline Pyrite $\left(\mathrm{FeS}_{2}\right)$ & 0.28 & 0.36 & - & - & - \\
\hline Hematite $\left(\mathrm{Fe}_{2} \mathrm{O}_{3}\right)$ & - & - & 0.74 & 0.73 & 0.51 \\
\hline Clinochlore $\left((\mathrm{Mg}, \mathrm{Fe}, \mathrm{Al})_{6}(\mathrm{Si}, \mathrm{All})_{4} \mathrm{O}_{10}(\mathrm{OH})_{8}\right.$ & 1.57 & 1.74 & - & - & - \\
\hline Calcite $\left(\mathrm{CaCO}_{3}\right)$ & 1.22 & 1.32 & - & - & - \\
\hline Halite (NaCl) & 0.33 & - & - & - & - \\
\hline Henelite $\left(\mathrm{Ca}_{2} \mathrm{Al}_{2} \mathrm{SiO}_{7}\right)$ & 0.71 & 0.83 & 1.73 & 1.68 & 3.28 \\
\hline $\mathrm{CaSO}_{4}$ & 0.99 & 2.65 & 3.16 & 2.40 & 1.54 \\
\hline $\mathrm{K}_{1,25} \mathrm{Al}_{1,25} \mathrm{Si}_{0,75} \mathrm{O}_{4}$ & 0.78 & 0.83 & - & - & - \\
\hline
\end{tabular}

it does not pass when $\Delta G_{\mathrm{T}}>0$. The software product HSC Chemistry 7.1 was used for calculation of Gibbs energy and equilibrium constant. These calculations were conducted within the temperature range $500-1400^{\circ} \mathrm{C}$.

Cast iron SCh20 (mass. \%: $3.4 \mathrm{C} ; 1.6 \mathrm{Si} ; 0.8 \mathrm{Mn}$; $0.1 \mathrm{~S} ; 0.05 \mathrm{P}$ ) and aqueous non-stick coating (with phase composition presented in the table 1) were chosen for researches [13].

The analysis displayed that composition of phase coating varies during heating, starting from the temperature $450{ }^{\circ} \mathrm{C}$; at the temperatures above $900{ }^{\circ} \mathrm{C}$ no variations of phase composition were observed.

The melting temperatures of most phases vary from 800 to $1500{ }^{\circ} \mathrm{C}\left(1392{ }^{\circ} \mathrm{C}\right.$ for diopside, $1145-1400{ }^{\circ} \mathrm{C}$ for muscovite, $1365{ }^{\circ} \mathrm{C}$ for helenite and $1450{ }^{\circ} \mathrm{C}$ for $\mathrm{CaSO}_{4}$ ), what is above the examined temperature range. Respectively, the quantitative variations can be connected with chemical interactions in the system "non-stick coating - atmosphere".

\section{The results of theoretical calculations}

Burning-on forming on iron and steel castings can be explained by metal surface oxidation and interaction between metal oxides and casting mould material. Low-melting silicates which strictly connect castings surface and casting mould (and thereby initiate burning-on forming) are the products of such interactions. It is evident that consideration of possibility of passing of iron oxidation reactions, forming of silicates and other probable reactions during the contact between the melt and non-stick coating is principally required for investigation of chemical interaction processes in the contact areas "melt - casting mould" and "melt - non-stick coating".

Only three kinds of iron oxides can exist in the system according to the $\mathrm{Fe}-\mathrm{O}$ phase equilibrium diagram [8]: $\mathrm{FeO}$ (melting temperature $1370{ }^{\circ} \mathrm{C}$ ), $\mathrm{Fe}_{2} \mathrm{O}_{3}$ (melting temperature $1597{ }^{\circ} \mathrm{C}$ ) and mixed oxide $\mathrm{Fe}_{3} \mathrm{O}_{4}$ (melting temperature above $1600{ }^{\circ} \mathrm{C}$ ).

Thermodynamic possibility of passing the reactions with iron and silicon, with forming of fayalite and pyroxene, is described in [9]. Chemical interaction between $\mathrm{SiO}_{2}$ and iron oxides $\mathrm{FeO}$ and $\mathrm{Fe}_{3} \mathrm{O}_{4}$ can be expressed by the following equations:

$\mathrm{FeO}+\mathrm{SiO}_{2} \rightarrow \mathrm{FeO} \cdot \mathrm{SiO}_{2}$ (pyroxene), $\mathrm{FeSiO}_{3}$

$\mathrm{Fe}_{3} \mathrm{O}_{4}+\mathrm{SiO}_{2} \rightarrow \mathrm{FeO} \cdot \mathrm{SiO}_{2}$ (pyroxene) $+\mathrm{Fe}_{2} \mathrm{O}_{3}$,

$2 \mathrm{FeO}+\mathrm{SiO}_{2} \rightarrow 2 \mathrm{FeO} \cdot \mathrm{SiO}_{2}$ (fayalite), $\mathrm{Fe}_{2} \mathrm{SiO}_{4}$

$2 \mathrm{Fe}_{3} \mathrm{O}_{4}+\mathrm{SiO}_{2} \rightarrow 2 \mathrm{FeO} \cdot \mathrm{SiO}_{2}$ (fayalite) $+2 \mathrm{Fe}_{2} \mathrm{O}_{3}$.

The analysis of calculated data for these reactions shows that $\Delta G_{T}$ has negative values in the whole researched temperature range. It is evidently required to create in the contact area "melt - casting mould" the conditions for lack of interaction between iron oxides $\mathrm{FeO}$ and $\mathrm{Fe}_{3} \mathrm{O}_{4}$ (from one side) and silicon oxide (from other side), to provide castings with clean surface [9].

This work supposes to use non-stick coating based on natural graphite in order to prevent the a.m. interaction. In this case, carbon as the main phase of graphite is oxidized under the effect of high temperature in the melt during cast iron pouring in a casting mould. This oxidation process is conducting in accordance to reactions presented in the table 2 .

Passing of reactions 1 and 2 is possible from the thermodynamic point of view, while reaction 3 will pass at the temperature above $300{ }^{\circ} \mathrm{C}$. Larger values of the equilibrium constants in reactions 1 and 2 testify that this reaction 2 will be more intensive.

The reactions of interaction between iron oxides (from one side) and carbon of non-stick coating and carbon oxides presenting in the casting mould atmosphere (from other side) are displayed on the fig. 1 and in the table 3 .

Reactions 4-6 describe reactions of interaction between iron oxides and solid carbon, reactions $7-11$ describe reactions of interaction between iron oxides and carbon (II) oxide, reactions $12-17$ describe reactions of interaction between iron oxides and carbon (IV) oxide. Passing of the reactions $7,13-15,17$ in the examined temperature range is impossible from the thermodynamic point of view.

\begin{tabular}{|c|c|c|c|c|c|c|}
\hline \multirow{3}{*}{$\begin{array}{l}\text { Tempe- } \\
\text { rature, } \\
{ }^{\circ} \mathrm{C}\end{array}$} & \multicolumn{6}{|c|}{ Reaction (number of reaction) } \\
\hline & \multicolumn{2}{|c|}{$\mathrm{C}_{\mathrm{sol}}+\mathrm{O}_{2 \mathrm{~g}}=\mathrm{CO}_{2 \mathrm{~g}}(1)$} & \multicolumn{2}{|c|}{$2 \mathrm{C}_{\mathrm{sol}}+\mathrm{O}_{2 \mathrm{~g}}=2 \mathrm{CO}_{\mathrm{g}}(2)$} & \multicolumn{2}{|c|}{$\mathrm{C}_{\mathrm{sol}}+\mathrm{CO}_{2 \mathrm{~g}}=2 \mathrm{CO}_{\mathrm{g}}(3)$} \\
\hline & $\begin{array}{c}\text { Gibbs } \\
\text { energy, kJ }\end{array}$ & $\begin{array}{c}\text { Equilibrium } \\
\text { constant }\end{array}$ & \begin{tabular}{|c|} 
Gibbs \\
energy, kJ
\end{tabular} & $\begin{array}{c}\text { Equilibrium } \\
\text { constant }\end{array}$ & $\begin{array}{c}\text { Gibbs } \\
\text { energy, } \mathrm{kJ}\end{array}$ & $\begin{array}{c}\text { Equilibrium } \\
\text { constant }\end{array}$ \\
\hline 500 & -395.51 & $5.29 \cdot 10^{26}$ & -360.22 & $2.18 \cdot 10^{24}$ & 35.29 & $4.13 \cdot 10^{-3}$ \\
\hline 600 & -395.68 & $4.71 \cdot 10^{23}$ & -378.08 & $4.17 \cdot 10^{22}$ & 17.59 & $8.86 \cdot 10^{-2}$ \\
\hline 700 & -395.82 & $1.77 \cdot 10^{21}$ & -395.83 & $1.77 \cdot 10^{21}$ & -0.02 & 1.00 \\
\hline 800 & -395.94 & $1.88 \cdot 10^{19}$ & -413.47 & $1.34 \cdot 10^{20}$ & -17.53 & 7.13 \\
\hline 900 & -396.04 & $4.38 \cdot 10^{17}$ & -430.98 & $1.55 \cdot 10^{19}$ & -34.94 & $3.60 \cdot 10$ \\
\hline 1000 & -396.12 & $1.79 \cdot 10^{16}$ & -448.39 & $2.50 \cdot 10^{18}$ & -52.27 & $1.40 \cdot 10^{2}$ \\
\hline 1100 & -396.19 & $1.18 \cdot 10^{15}$ & -465.70 & $5.21 \cdot 10^{17}$ & -69.51 & $4.41 \cdot 10^{2}$ \\
\hline 1200 & -396.24 & $1.13 \cdot 10^{14}$ & -482.90 & $1.33 \cdot 10^{17}$ & -86.66 & $1.18 \cdot 10^{3}$ \\
\hline 1300 & -396.28 & $1.44 \cdot 10^{13}$ & -500.02 & $4.02 \cdot 10^{16}$ & -103.73 & $2.78 \cdot 10^{3}$ \\
\hline 1400 & -396.31 & $2.36 \cdot 10^{12}$ & -517.04 & $1.39 \cdot 10^{16}$ & -120.73 & $5.88 \cdot 10^{3}$ \\
\hline
\end{tabular}




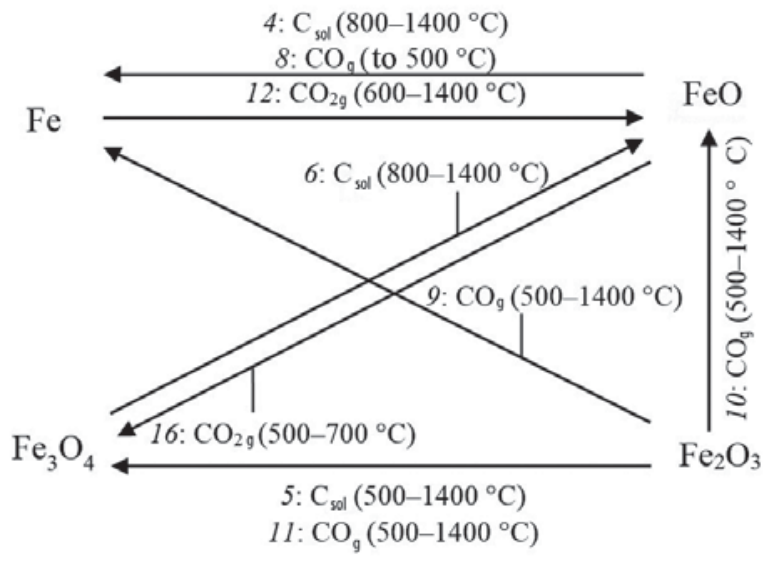

Fig. 1. Interaction scheme according to the reactions: $1,2, \ldots .$. - number of reactions in accordance with the table 1 . Temperature range for available reaction passing is given in brackets
The equilibrium constant of reaction 8 (at the temperature $500^{\circ} \mathrm{C}$ ) is equal to 1.29 ; for the reactions 16 (within the range $500-700^{\circ} \mathrm{C}$ ) and 12 (within the range $600-1400^{\circ} \mathrm{C}$ ) this constant is equal to $1.74-1.02$ and $1.1-3.48$ respectively. Thereby it can be concluded that possibility of these reactions is low because the equilibrium constants are close to 1 . I.e. the initial substances and products are presented in an equilibrium system approximately in equal amounts.

The equilibrium constant in the temperature range 800 $1400{ }^{\circ} \mathrm{C}$ for reactions 4 and 6 increases from 4.05 to $1.69 \cdot 10^{3}$ and from 8.12 to $1.33 \cdot 10^{4}$ respectively, so speed of reactions eill rise with temperature increase.

Reactions 5 and 9-11, i.e. reactions of carbon (II) oxide and iron (II) oxide are characterized by the most passing probability from thermodynamic point of view for different stoichiometric relationship. It is connected with negative values of Gibbs energy for these reactions in the whole examined temperature range. The values of equilibrium constants for these reactions in the examined temperature range vary from $3.44 \cdot 10^{9}$ to $5.12 \cdot 10^{12}$ (for reaction 5); from $11.1 \cdot 10^{2}$ to 4.41 (for reaction 9); from $9.13 \cdot 10^{5}$ to $2.97 \cdot 10^{4}$ (for reaction 10) and from 67.15 to 53.28 (for reaction 11 ). Thereby the reaction 5 will have the most passing possibility.

Thermodynamic calculations of interaction reactions between solid carbon and metal oxides (which are forming as a result of decomposition of impurity phases) displayed that passing of these reactions is slightly possible even at very high temperatures; the small values of equilibrium constants and Gibbs energy (see table 4) testify on this tendency.

Reactions of interaction between iron and sulfur oxides are displayed on the fig. 2 and in the table 5 .

\begin{tabular}{|c|c|c|c|c|c|c|c|c|c|c|c|}
\hline \multirow{2}{*}{$\begin{array}{c}\text { Number } \\
\text { of reaction }\end{array}$} & \multirow{2}{*}{ Reactions } & \multicolumn{10}{|c|}{ Gibbs energy values $(\mathrm{kJ})$ at the temperature $\left({ }^{\circ} \mathrm{C}\right)$} \\
\hline & & 500 & 600 & 700 & 800 & 900 & 1000 & 1100 & 1200 & 1300 & 1400 \\
\hline 4 & $\mathrm{C}_{\mathrm{sol}}+\mathrm{FeO}=\mathrm{Fe}+\mathrm{CO}_{\mathrm{g}}$ & 33.67 & 18.28 & 2.92 & -12.47 & -27.88 & -43.28 & -58.56 & -73.73 & -88.80 & -103.40 \\
\hline 5 & $\mathrm{C}_{\mathrm{sol}}+6 \mathrm{Fe}_{2} \mathrm{O}_{3}=4 \mathrm{Fe}_{3} \mathrm{O}_{4}+\mathrm{CO}_{2 \mathrm{~g}}$ & -141.13 & -171.74 & -202.36 & -232.24 & -262.05 & -291.66 & -320.99 & -350.02 & -378.77 & -407.27 \\
\hline 6 & $\mathrm{C}_{\mathrm{sol}}+\mathrm{Fe}_{3} \mathrm{O}_{4}=3 \mathrm{FeO}+\mathrm{CO}_{\mathrm{g}}$ & 38.84 & 19.17 & 0.12 & -18.69 & -37.40 & -56.08 & -74.77 & -93.49 & -112.25 & -132.04 \\
\hline 7 & $5 \mathrm{CO}_{\mathrm{g}}+\mathrm{Fe}=\mathrm{Fe}(\mathrm{CO})_{5}$ & 291.41 & 349.89 & 406.97 & 462.75 & 517.21 & 570.35 & 622.08 & 672.38 & 721.28 & 768.75 \\
\hline 8 & $\mathrm{CO}_{\mathrm{q}}+\mathrm{FeO}=\mathrm{Fe}+\mathrm{CO}_{2 \mathrm{~g}}$ & -1.63 & 0.69 & 2.94 & 5.05 & 7.07 & 8.99 & 10.95 & 12.93 & 14.94 & 17.33 \\
\hline 9 & $3 \mathrm{CO}_{\mathrm{g}}+\mathrm{Fe}_{2} \mathrm{O}_{3}=2 \mathrm{Fe}+3 \mathrm{CO}_{2 \mathrm{~g}}$ & -30.29 & -29.13 & -27.76 & -26.46 & -25.36 & -24.46 & -23.53 & -22.59 & -21.64 & -20.64 \\
\hline 10 & $\mathrm{CO}_{\mathrm{g}}+\mathrm{Fe}_{2} \mathrm{O}_{3}=2 \mathrm{FeO}+\mathrm{CO}_{2 \mathrm{~g}}$ & -27.04 & -30.51 & -33.63 & -36.56 & -39.49 & -42.44 & -45.43 & -48.45 & -51.51 & -55.30 \\
\hline 11 & $\mathrm{CO}_{\mathrm{g}}+3 \mathrm{Fe}_{2} \mathrm{O}_{3}=\mathrm{Fe}_{3} \mathrm{O}_{4}+\mathrm{CO}_{2 \mathrm{~g}}$ & -88.21 & -94.66 & -101.17 & -107.36 & -113.55 & -119.70 & -125.74 & -131.68 & -137.52 & -143.27 \\
\hline 12 & $\mathrm{CO}_{2 \mathrm{q}}+\mathrm{Fe}=\mathrm{FeO}+\mathrm{CO}_{\mathrm{q}}$ & 1.63 & -0.69 & -2.94 & -5.05 & -7.07 & -8.99 & -10.95 & -12.93 & -14.94 & -17.33 \\
\hline 13 & $3 \mathrm{CO}_{2 \mathrm{~g}}+2 \mathrm{Fe}=\mathrm{Fe}_{2} \mathrm{O}_{3}+3 \mathrm{CO}_{\mathrm{g}}$ & 30.29 & 29.13 & 27.76 & 26.46 & 25.36 & 24.46 & 23.53 & 22.59 & 21.64 & 20.64 \\
\hline 14 & $2 \mathrm{CO}_{2 \mathrm{~g}}+3 \mathrm{Fe}=2 \mathrm{Fe}_{3} \mathrm{O}_{4}+3 \mathrm{CO}_{\mathrm{g}}$ & 1124.14 & 1122.81 & 1120.94 & 1119.16 & 1117.51 & 1116.03 & 1114.43 & 1112.73 & 1110.95 & 1109.02 \\
\hline 15 & $\mathrm{CO}_{2 \mathrm{~g}}+2 \mathrm{FeO}=\mathrm{Fe}_{2} \mathrm{O}_{3}+\mathrm{CO}_{\mathrm{g}}$ & 27.04 & 30.51 & 33.63 & 36.56 & 39.49 & 42.40 & 45.43 & 48.45 & 51.51 & 55.30 \\
\hline 16 & $\mathrm{CO}_{2 \mathrm{q}}+3 \mathrm{FeO}=\mathrm{Fe}_{3} \mathrm{O}_{4}+\mathrm{CO}_{\mathrm{g}}$ & -3.55 & -1.58 & -0.14 & 1.16 & 2.46 & 3.81 & 5.27 & 6.83 & 8.51 & 11.31 \\
\hline 17 & $\mathrm{CO}_{2 \mathrm{~g}}+2 \mathrm{Fe}_{3} \mathrm{O}_{4}=3 \mathrm{Fe}_{2} \mathrm{O}_{3}+\mathrm{CO}_{\mathrm{q}}$ & 88.21 & 94.66 & 101.17 & 107.36 & 113.55 & 119.70 & 125.74 & 131.68 & 137.52 & 143.27 \\
\hline
\end{tabular}




\begin{tabular}{|c|l|c|c|c|}
\hline \multicolumn{1}{|c|}{ Table 4. Reactions of interaction between oxides and solid carbon } & \multicolumn{1}{l|}{ Equilibrium constant } \\
\hline $\begin{array}{c}\text { Number } \\
\text { of reaction }\end{array}$ & \multicolumn{1}{c|}{ Reaction } & $\begin{array}{c}\text { Temperature, }{ }^{\circ} \mathrm{C} \\
\text { (reaction is passing above it) }\end{array}$ & $\begin{array}{c}\text { Gibbs energy at this } \\
\text { temperature, } \mathrm{kJ}\end{array}$ & 2,38 \\
\hline 18 & $3 \mathrm{C}_{\text {sol }}+\mathrm{CaO}=\mathrm{CaC}_{2}+\mathrm{CO}_{\mathrm{g}}$ & 1900 & $-3,750$ & 1,00 \\
\hline 19 & $10 \mathrm{C}_{\text {sol }}+2 \mathrm{Al}_{2} \mathrm{O}_{3}=\mathrm{Al}_{4} \mathrm{C}_{4}+6 \mathrm{CO}_{\mathrm{g}}$ & 2000 & $-0,012$ & 1,99 \\
\hline 20 & $10 \mathrm{C}_{\mathrm{sol}}+2 \mathrm{SiO}_{2}=\mathrm{Si}+2 \mathrm{CO}_{\mathrm{g}}$ & 1700 & $-2,702$ & 5,24 \\
\hline 21 & $2 \mathrm{C}_{\mathrm{sol}}+\mathrm{SiO}_{2}=\mathrm{SiC}+2 \mathrm{CO}_{\mathrm{g}}$ & 1600 & $-6,163$ & 2,74 \\
\hline 22 & $\mathrm{~K}_{2} \mathrm{O}_{\mathrm{sol}}+\mathrm{C}=2 \mathrm{~K}+\mathrm{CO}_{\mathrm{g}}$ & 900 & $-2,353$ & \\
\hline
\end{tabular}

\begin{tabular}{|c|c|c|c|c|c|c|c|c|c|c|c|}
\hline \multirow{2}{*}{$\begin{array}{l}\text { Number } \\
\text { of reaction }\end{array}$} & \multirow{2}{*}{ Reactions } & \multicolumn{10}{|c|}{ Gibbs energy values $(\mathrm{kJ})$ at the temperature $\left({ }^{\circ} \mathrm{C}\right)$} \\
\hline & & 500 & 600 & 700 & 800 & 900 & 1000 & 1100 & 1200 & 1300 & 1400 \\
\hline 19 & $4 \mathrm{FeS}_{2}+11 \mathrm{O}_{2 \mathrm{~g}}=2 \mathrm{Fe}_{2} \mathrm{O}_{3}+8 \mathrm{SO}_{2 \mathrm{~g}}$ & -3098.49 & -3068.34 & -3039.05 & -3010.35 & -2981.84 & -2953.45 & -2925.18 & -2896.99 & -2868.87 & -2840.80 \\
\hline 20 & $\mathrm{SO}_{2 \mathrm{~g}}+\mathrm{FeO}=\mathrm{Fe}+\mathrm{SO}_{3 \mathrm{~g}}$ & 174.28 & 176.55 & 179.14 & 181.91 & 184.77 & 187.70 & 190.55 & 193.35 & 196.01 & 198.56 \\
\hline 21 & $4 \mathrm{SO}_{2 \mathrm{~g}}+2 \mathrm{Fe}_{2} \mathrm{O}_{3}=4 \mathrm{FeS}+7 \mathrm{O}_{2 \mathrm{~g}}$ & 1004.58 & 976.19 & 948.23 & 920.58 & 893.02 & 865.50 & 837.97 & 811.93 & 780.01 & 748.14 \\
\hline 22 & $6 \mathrm{SO}_{2 \mathrm{q}}+2 \mathrm{Fe}_{2} \mathrm{O}_{3}+3 \mathrm{O}_{2 \mathrm{q}}=2 \mathrm{Fe}_{2}\left(\mathrm{SO}_{4}\right)_{3}$ & -458.64 & -295.75 & -133.33 & 28.46 & 189.29 & 349.18 & 08.16 & 666.29 & 823.60 & 980.11 \\
\hline 23 & $4 \mathrm{SO}_{2 \mathrm{q}}+2 \mathrm{Fe}_{2} \mathrm{O}_{3}+\mathrm{O}_{2 \mathrm{q}}=4 \mathrm{FeSO}_{4}$ & -201.05 & -115.21 & -29.66 & 55.41 & 139.67 & 223.14 & 305.85 & 387.83 & 469.12 & 549.74 \\
\hline 24 & $2 \mathrm{SO}_{2 \mathrm{~g}}+\mathrm{Fe}_{2} \mathrm{O}_{3}+7 \mathrm{CO}_{\mathrm{g}}=2 \mathrm{FeS}+7 \mathrm{CO}_{2 \mathrm{~g}}$ & -503.23 & -470.25 & -437.08 & -403.86 & -370.82 & -338.00 & -305.43 & -271.61 & -243.90 & -216.37 \\
\hline 25 & $\mathrm{SO}_{2 \mathrm{~g}}+\mathrm{Fe}_{3} \mathrm{O}_{4}=3 \mathrm{FeO}+\mathrm{SO}_{3 \mathrm{~g}}$ & 192.84 & 191.43 & 190.55 & 189.79 & 189.04 & 188.22 & 187.31 & 186.28 & 185.14 & 182.88 \\
\hline 26 & $\mathrm{SO}_{2 \mathrm{~g}}+2 \mathrm{FeS}+5 \mathrm{O}_{2 \mathrm{~g}}=\mathrm{Fe}_{2}\left(\mathrm{SO}_{4}\right)_{3}$ & -1233.90 & -1124.07 & -1014.89 & -906.35 & \begin{tabular}{|l|}
-798.38 \\
\end{tabular} & -690.91 & -583.89 & -478.79 & -368.22 & -258.09 \\
\hline 27 & $\mathrm{SO}_{2 \mathrm{q}}+\mathrm{O}_{2 \mathrm{q}}=\mathrm{SO}_{3 \mathrm{~g}}$ & -52.21 & -33.55 & -14.98 & 3.50 & 21.90 & 40.21 & 58.46 & 76.64 & 94.75 & 112.80 \\
\hline 28 & $3 \mathrm{SO}_{3 \mathrm{~g}}+\mathrm{Fe}_{2} \mathrm{O}_{3}=\mathrm{Fe}_{2}\left(\mathrm{SO}_{4}\right)_{3}$ & -151.00 & -97.55 & -44.19 & 8.98 & 61.80 & 114.27 & 166.39 & 218.19 & 269.67 & 320.85 \\
\hline 29 & $\mathrm{SO}_{3 \mathrm{~g}}+\mathrm{FeO}=\mathrm{FeSO}_{4}$ & -28.28 & -23.92 & -19.61 & -15.35 & -11.13 & -6.95 & -2.80 & 1.31 & 5.38 & 9.51 \\
\hline 30 & $6 \mathrm{SO}_{3 \mathrm{~g}}+2 \mathrm{Fe}_{3} \mathrm{O}_{4}=6 \mathrm{FeS}+13 \mathrm{O}_{2 \mathrm{~g}}$ & 727.34 & 697.24 & 667.52 & 638.00 & 608.60 & 579.26 & 549.93 & 521.70 & 48925 & 456.86 \\
\hline
\end{tabular}

Despite small pyrite content in the coating (up to 1 mass. $\%)$, it can have significant effect on the processes of burningon forming due to forming of oxysulfates and oxysulfides which have less surface tension in comparison with iron melt. It supports melt penetration of mould pores and forming of mechanical burning-on. It is connected with pyrite oxidation by air oxygen at $500-800{ }^{\circ} \mathrm{C}$ with forming of $\mathrm{Fe}_{2} \mathrm{O}_{3}$ and $\mathrm{SO}_{2}$ (see reaction 19 in the table 5). Possibility of passing of this reaction is rather high.

Forming sulfur oxide $\mathrm{SO}_{2}$ can react with iron oxides (reactions $20-25$, table 5 , fig. 2) and with iron sulfide in oxygen presence (reaction 26, table 5, fig. 2) and with oxygen itself (reaction 27, table 5, fig. 2).

Interaction between $\mathrm{Fe}_{2} \mathrm{O}_{3}$ and $\mathrm{SO}_{2}$ in the presence of $\mathrm{O}_{2}$ occurs at the temperatures up to $700^{\circ} \mathrm{C}$ (reactions 22,23 , table 5 , fig. 2). The equilibrium constant at the temperature $700{ }^{\circ} \mathrm{C}$ for the reaction 22 makes $1.44 \cdot 10^{7}$, and for the reaction $23-39.1$, what testifies on more intensive passing of the reaction 22 .

Interaction between $\mathrm{Fe}_{2} \mathrm{O}_{3}$ and $\mathrm{SO}_{2}$ is also possible in the presence of $\mathrm{CO}$ in the whole examined temperature range (the reaction 24 , table 5 , fig. 2); the equilibrium constant varies from $2.9 \cdot 10^{128}$ (at the temperature $500{ }^{\circ} \mathrm{C}$ ) to $7.38 \cdot 10^{13}$ (at the temperature $1400^{\circ} \mathrm{C}$ ).

In addition to described reactions, sulfur (IV) oxide interacts with oxygen and forms sulfur (VI) oxide. This reaction is possible at the temperatures below $700^{\circ} \mathrm{C}$ (the reaction 27 , table 5 , fig. 2). $\mathrm{SO}_{3}$, in its turn, can react with $\mathrm{Fe}_{2} \mathrm{O}_{3}$ (the reaction 28, table 5, fig. 2) at the temperatures below $700{ }^{\circ} \mathrm{C}$ and with $\mathrm{FeO}$ (the reaction 29, table 5, fig. 2) at the temperatures below $1100^{\circ} \mathrm{C}$, while there will not be any interaction with $\mathrm{Fe}_{3} \mathrm{O}_{4}$, according to the calculations (the reaction 30, table 5, fig. 2). Comparison of equilibrium constants shows that the reaction 29 passes more intensively than the reaction 28 at the temperatures below $700{ }^{\circ} \mathrm{C}$ (the values of equilibrium constants of these reactions 28 and 29 are equal respectively to $2.36 \cdot 10^{2}$ and $2.54 \cdot 10^{4}$ ).
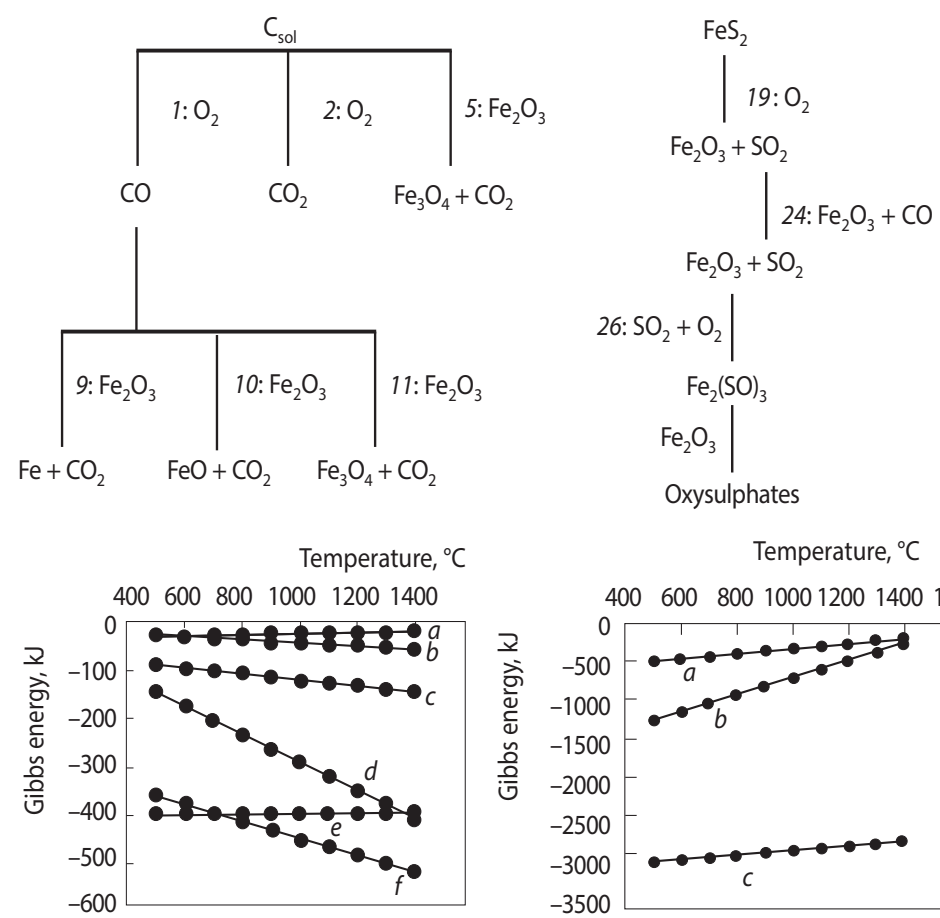

Temperature, ${ }^{\circ} \mathrm{C}$

4006008001000120014001600

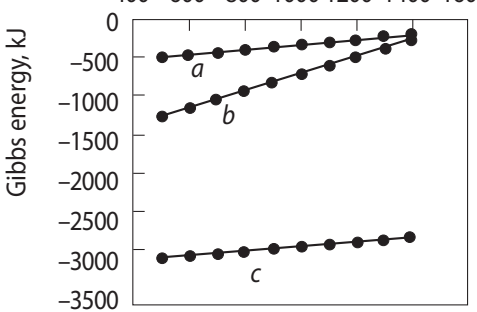

Fig. 3. The main interactions at the boundary "melt - coating" 
Thereby, passing of the reactions 1, 2, 5, 9, 10, 19, 24 and 26 (fig. 3) in the casting mould cavity on the boundary "iron melt - non-stick coating" is possible.

The required conditions for prevention of interaction between oxides $\mathrm{FeO}$ and $\mathrm{Fe}_{3} \mathrm{O}_{4}$ (from one side) and silicon oxide (from other side) in the contact area "iron melt - casting mould" are created owing to forming of reducing atmosphere via increase of content of carbon (II) oxide as a result of oxidation of non-stick coating carbon. Forming carbon (II) dioxide is consumed on partial reduction of iron (III) oxide, what decreases possibility of forming of fayalite and pyroxene. At the same time, transition of carbon (II) oxide into carbon (IV) oxide takes place, i.e. reducing atmosphere becomes a neutral one (fig. 3,a). From the other side, strong reducing properties of $\mathrm{CO}$ allow sulfur compounds to reduce from sulfur oxides which are forming in the atmosphere of a casting mould due to pyrite oxidation (this pyrite presents in composition of non-stick coating) (fig. $3, b$ ). Iron (II) sulfide and iron (II) sulfate react with iron (III) and form iron oxysulfides and oxysulfates which support burning-on forming on the surface of castings [13].

Thereby, it is necessary to remove sulfur-containing components (such as pyrite) out of coating composition or to transit them to compounds which are not forming during mould pouring by the melt of oxysulfides and oxysulfates in order to provide operating efficiency rise of coating. It can be achieved by activation of natural graphite, what confirm the previously obtained experimental data [13].

\section{Conclusions}

Thereby, thermodynamic analysis of chemical reactions of interaction between melt oxides and filling agent of non-stick coating allows to synthesize the required compositions of non-stick coatings and to predict their operating efficiency. It was determined in the work that:

- creation of oxidizing $(\mathrm{CO})$ atmosphere in the contact area "iron melt - casting mould" is the necessary condition to prevent interaction between $\mathrm{FeO}$ and $\mathrm{Fe}_{3} \mathrm{O}_{4}$ oxides (from one side) and silicon oxide (from other side), what decreases possibility of fayalite and pyroxene forming;

- presence of pyrite in the coating composition leads through the chain of oxidizing and reducing processes to forming of oxysulfides and oxysulfates which support burning-on forming on the surface of castings.

To rise operating efficiency, it is recommended to conduct additional chemical or chemical-mechanical graphite activation which allows to decrease content of sulfur-containing components (pyrite) in composition of non-stick coatings.

\section{REFERENCES}

1. Shvetsov V. I., Ivanov M. A., Kulakov B. A., Karkarin A. M. Processes of forming and prevention of burning-on on steel casings. Vestnik Yuzhno-Uralskogo gosudarstvennogo universiteta. Seriya: Metallurgiya. 2015. Vol. 15. No. 1. pp. 17-23.

2. Chen-Cheng Sun, Lee Shih-Chin, Dai Shyue-Bin et al. Surface free energy of non-stick coatings deposited using closed field unbalanced magnetron sputter ion plating. Applied surface science. 2007. Vol. 253. Iss. 8. pp. 4094-4098.

3. Rodriguez-Alabanda O., Molleja Molleja R., Guerrero-Vaca G., Romero P. E. Direct manufacturing of non-stick molds via single point incremental forming. Procedia Manufacturing. 2019. Vol. 41 pp. $1135-1140$.

4. Kukuy D. M., Andriyanov N. V. Theory and technology of casting production. Moulding materials and mixtures. Minsk : BNTU. 2005. $390 \mathrm{p}$

5. Illarionov I. E., Vasin Yu. P. Moulding materials and mixtures. Cheboksary : Izdatelstvo Chuvashskogo gosudarstvennogo universiteta. 1995. Part 2. 288 p

6. Illarionov I. E., Gamov E. S., Vasin Yu. P., Chernyshevich E. G. Metal phosphate binding agents and mixtures. Cheboksary : Izdatelstvo Chuvashskogo gosudarstvennogo universiteta. 1995. Part 2. $524 \mathrm{p}$.

7. Zhukovskiy S. S., Anisovich N. N. et al. Moulding materials and technology of casting mould. Edited by Zhukovskiy S. S. M. : Mashinostroenie. 1993. 432 p.

8. Nikolaichik Yu. A., Rudnitskiy F. I., Bataichuk A. V., Mudryi V. V. Analysis of the methods for burning-on prevention on the surface of iron and steel castings. Lityo i metallurgiya. 2015. No. 1 (78). pp. 23-28.

9. Kukuy D. M., Nikolaichik Yu. A., Sudnik L. V. Thermodynamic analysis of chemical reactions in the contact area "metal - non-stick coating". Lityo i metallurgiya. 2010. No. 3 (57). pp. 51-56.

10. Nikitchenko M. N., Semukov A. S., Saulin D. V., Yaburov A. Yu. Study of thermodynamic possibility of interaction between materials of casting mould and metal during casting of titanium alloys. Vestnik PNIPU. 2017. No. 4. pp. 249-263.

11. Ovcharenko, P. G., Kuzminykh E. V., Ladyanov V. I. Interaction of a Nonstick Corundum Coating with Iron-Carbon Melts under Lost-Foam Casting. Russian Metallurgy (Metally). 2020. No. 2. pp. $115-120$.

12. Kalistov S. V., Leushin I. O., Gerotskiy V. A. Thermodynamic analysis of the process of steel melt carbonization in manufacture of synthetic iron. Sotsialno-ekonomicheskie i tekhnicheskie sistemy: isslrdovanie, proektirovanie, optimizatsiya. 2008. No. 9. p. 3.

13. Babkin V. G., Leonov V. V., Gilmanshina T. R., Stepanova T. N. Phase transformations in graphite coatings and their effect on surface cleanness of castings. Chernye metally. 2017. No. 10. pp. 54-59.

14. Gilmanshina T. R., Lytkina S. I., Khudonogov S. A. et al. Development of the state-of-the-art technologies for improvement of quality of cryptocrystalline graphite. Nanosistemi, Nanomateriali, Nanotehnologii. 2018. Vol. 16 (1). pp. 83-101.

15. Amelchenko V. N., Illarionov I. E., Gilmanshina T. R., Borisyuk V. A. Graphite as a prospective material for metallurgical application. CIS Iron and Steel Review. 2018. Vol. 16. pp. 29-32.

16. Bannykh O. A., Budberg P. B., Alisova S. P. et al. Phase equilibrium diagrams of iron-based dual and multi-component systems. M. : Metallurgiya. 1986. $440 \mathrm{p}$. 